German Council for Social and Economic Data (RatSWD)

\title{
RatSWD
}
Working Paper
No. 95

\section{Measuring vocational competencies}

Martin Baethge and Lena Arends

July 2009 


\section{Working Paper Series of the Council for Social and Economic Data}

(RatSWD)

The RatSWD Working Papers series was launched at the end of 2007. Since 2009, the series has been publishing exclusively conceptual and historical works dealing with the organization of the German statistical infrastructure and research infrastructure in the social, behavioral, and economic sciences. Papers that have appeared in the series deal primarily with the organization of Germany’s official statistical system, government agency research, and academic research infrastructure, as well as directly with the work of the RatSWD. Papers addressing the aforementioned topics in other countries as well as supranational aspects are particularly welcome.

RatSWD Working Papers are non-exclusive, which means that there is nothing to prevent you from publishing your work in another venue as well: all papers can and should also appear in professionally, institutionally, and locally specialized journals. The RatSWD Working Papers are not available in bookstores but can be ordered online through the RatSWD.

In order to make the series more accessible to readers not fluent in German, the English section of the RatSWD Working Papers website presents only those papers published in English, while the the German section lists the complete contents of all issues in the series in chronological order.

Starting in 2009, some of the empirical research papers that originally appeared in the RatSWD Working Papers series will be published in the series RatSWD Research Notes.

The views expressed in the RatSWD Working Papers are exclusively the opinions of their authors and not those of the RatSWD.

The RatSWD Working Paper Series is edited by:

Chair of the RatSWD (2007/ 2008 Heike Solga; 2009 Gert G. Wagner)

Managing Director of the RatSWD (Denis Huschka) 


\section{Measuring vocational competencies}

\section{Martin Baethge and Lena Arends}

Soziologisches Forschungsinstitut Göttingen

(martin.baethge[a]sofi.uni-goettingen.de; larends1[at]gwdg.de) 


\section{The political dimension of measurement in Vocational Education and Training}

The increasing internationalisation of labour markets and VET as well as recent initiatives to improve transparency in VET - i.e., the proposals for a European Qualification Framework (EQF) and a European Credit System for Vocational Education and Training (ECVET) - have shifted the debate on transparency and quality standards in VET to the policy level.

The European Commission has put forward the ambitious economic and social goal of becoming "the most competitive and dynamic knowledge-based economy in the world" (Lisbon European Council, March 2000). In the field of VET this aim is being pursued through the Copenhagen Process. The European Commission's proposal for a European Qualifications Framework (EQF) offers opportunities to increase mobility and enhance permeability between educational sectors. By means of closer cooperation in VET, further developing VET systems. In the recent progress report of the European Commission towards the Lisbon objectives it is emphasised that "internationally comparable large scale assessments programmes often concentrate on general competences (e.g. reading, information processing, numeracy and problem solving) whereas many employers argue that "there is an increasing need to conduct surveys which focus as well on the assessment of vocational skills and competences” (European Commission 2008, 58).

There are no indicators for international benchmarking of VET (below Higher Education). The International Standards Classification of Education (ISCED, UNESCO 1997) does not provide a tool for comparing the performance of VET-systems in different countries because the levels for classifying different VET programmes are not transparent enough ${ }^{1}$ (Müller, 2008).

An international comparable, objective, valid and reliable assessment of cross-country differences in the level and distribution of vocational competences could provide a scientific basis for the debates on the EQF and the ECVET; the results will allow a better classification of national educational programmes in existing classification systems (e.g., NQF/EQF, ISCED) on an empirical basis.

1 In particular ISCED 3B/3C, 4 and 5B. 


\section{Current state of competence measurement in VET}

\section{Large-scale assessments in education}

There is general consensus that indicators for measuring quality are key instruments for improving the quality of education and training necessary for the good governance of education systems and structures (European Commission - DG EAC, 2004). International comparative studies (e.g., PISA, IALS) provide standardised and internationally comparable indicators that give insights into the factors influencing the development of competences of students in compulsory education and adults in everyday life. These indicators provide policy makers with a tool on which to base future policy choices.

The measurement of competences has become an instrument for benchmarking the performance of educational systems. During the past 15 years, considerable experience has been gained in the development and implementation of large-scale assessments in education. International tests have been developed for measuring basic skills of students in compulsory education and generic skills of adults in everyday life, tests for measuring competences in specific vocational areas are still missing.

There are three major surveys for the measurement of basic skills of students in compulsory education: the TIMSS ${ }^{2}$ survey, which is focused on the mathematics and science aptitudes of students in the 4th and the 8th grade in a number of countries; the PIRLS ${ }^{3}$ survey, in which reading literacy of $4^{\text {th }}$ graders was measured; and the PISA-study ${ }^{4}$, which assesses the literacy, numeracy, science, and problem-solving performance of 15-year olds. PISA has become a major policy tool for measuring students' competencies in comparison to other countries, for establishing benchmarks of educational improvement, and for representing strengths and weaknesses of national educational systems.

For measuring the skills of adults, two surveys have been implemented: The IALS ${ }^{5}$ survey was the first attempt to implement a large-scale adult skills assessment based on tests on an international basis (OECD and Statistics Canada 2005). The ALL survey builds on the IALS survey by extending the range of competency domains and improving the quality of assessment methods (Murray and Clermont 2005). The Adult Literacy and Life-skills (ALL) Survey ${ }^{6}$ is the most comprehensive programme for measuring adult skills (16-65 years) in the following domains:

\footnotetext{
The Trends in International Mathematics and Science Study (TIMSS) was implemented first in 1995.

The Progress in International Reading Literacy Study (PIRLS) was implemented in 2001.

The Programme for International Student Assessment (PISA) started in the mid-1990s.

The International Adult Literacy Survey (IALS) was administered in 1994, 1996 and 1998.

The assessment was conducted in 2003 in people's homes in seven countries: Bermuda, Canada, Italy, Norway, Switzerland, United States, Nuevo León.
} 
- prose literacy,

- document literacy,

- numeracy, and

- problem solving.

The ALL framework is based on an all-encompassing skill typology with the all skills that are relevant for everybody in a variety of life contexts (e.g., community, home, work). Skills for work are based on employability skill models based on general skill categories that are applicable across a variety of working situations.

Building on the ALL survey, the OECD has launched an international study of financial literacy of adults in twelve OECD countries; assessment is focused on financial literacy in everyday live contexts of adults as consumers, workers, and citizens (OECD 2005; 2008).

Following up on the IALS and ALL surveys, the OECD is currently developing a strategy for assessing the literacy skills of adults, including familiarity with information, and communication technologies and the ability to manage information, construct new knowledge and communicate with others (Schleicher 2008). In the first cycle, measurement in PIAAC ${ }^{7}$ will be implemented in three areas:

- Direct assessment of cognitive skills: Integrated measurement of broad literacy competence encompassing the range of performance from mastery of the basic building blocks of literacy to the capacity of effectively managing complex information processing tasks embedded in an Information Technology (IT) setting. Up to four areas of competences will be assessed: "Problem-solving in a technology-rich environment”, “Literacy”, “Numeracy”; and "Literacy component skills”.

- Indirect assessment of skills used in the workplace: The $\mathrm{JRA}^{8}$ module seeks to assess the level and use of a number of generic skills such as communication, presentation and team-working skills, in the workplace. With the JRA module, individuals will be asked set of questions relating to their job and the requirements of that job in terms of the intensity and frequency of the use of certain skills. ${ }^{9}$

- Background questionnaire: The aim is to collect information relating to the antecedents and outcomes of adult literacy competences, including information on literacy practices and familiarity with and usage of information technology.

7 Programme for the International Assessment of Adult Competences. PIAAC is currently being implemented with a view to undertake a first assessment in 2011. The main survey design is based on a minimum main study sample size per country of 5,000 adults, aged 1664.

8 Jobs Requirement Approach (JRA)

9 Given that the approach is untested in an international survey, a pilot of the JRA module is currently taking place to test the validity and reliability of this approach in a cross-country and cross-cultural context. 
- None of the illustrated surveys for cross-country differences in the level and distribution of competences of students and adults is focused on the assessment of domain-specific competences in specific vocational areas.

\section{Approaches for measurement in VET}

The term competence is one of the most diverse notions in the field of education and educational policy. Efforts to define the term have remained unsuccessful because a variety of topics are addressed under the heading of 'competence` (e.g. Descy and Tessaring 2005; Arends 2005). In some concepts `competences` refer to internal conditions of individuals to master tasks in different situations successfully whereas in others, 'competences` refer to tasks and situational requirements itself. For the comparison of the performance of different VET-systems and -programmes, we differentiate between two approaches for measurement: Measurement of individuals internal conditions to master (occupational) task successfully and measurement individuals external performance in different (occupational) situations. Following PISA, we are in favour of approaches for measuring internal conditions in the field of VET. In this approach, individuals are carriers of competences; they have developed the ability and willingness to successfully apply their knowledge, abilities and experiences to authentic (occupational) situations. For the measurement of internal conditions, internationally valid models of the structure and development of competences in specific domains (e.g., literacy, numeracy in PISA) at different levels of complexity are needed..$^{10}$

The development and implementation of internationally valid tests for measuring internal conditions is considered a time consuming, expensive and methodologically challenging task (e.g., item development in PISA). To overcome this, many skills surveys tried to identify less time consuming and expensive approaches for competence measurement on the basis of external performance. Typically, external measurement is implemented in direct observations of individuals during work performance (e.g., work samples) or self assessments of work activities (e.g., JRA approach). For example, the UK Skills Survey (Ashton et al. 1999; Felstead et al. 2002) and the O*NET database (US Occupational Information Network) are based on the Job Requirement Approach (JRA), a self-assessment instrument for individuals to rate their competences at the workplace.

Toolsema (2003) adopted the GWA concept from O*NET ${ }^{11}$ identifying and comparing competences. In O*NET, Generalized Work Activities (GWA) are aggregations of similar job

10 In VET, models for measuring competences in different vocational areas are currently being developed (e.g., Winther. and Achtenhagen 2008; Nickolaus et al. 2008).

11 Occupational Information Network from the US 
activities/behaviours that underlie the accomplishment of major work functions" (Jeanneret et al. 1999, 106). The central assumption is that work behaviour is not necessarily linked to specific tasks and techniques and, therefore, can be located at a higher level of aggregation. Activities are considered competence indicators at a higher level of abstraction, indicating the purpose of competences. Toolsema derived six competence categories - social, participative, cognitive, physical- /technical, learning, and employability - , and linked them with GWAs. The instrument was applied for measuring cognitive, affective, and meta-cognitive aspects of performance at different levels of abstraction in the field of Higher Education, not in VET.

A different external approach was used in the VQTS model. ${ }^{12}$ The aim was to provide a structured description of work-related competences and their acquisition. By using a competence matrix, which displays the competences of a specific occupational field at different levels, the model aims to provide an instrument for VET providers to transfer and recognise competences acquired within the official VET systems in foreign countries (LuomiMesserer and Markowitsch 2006; Markowitsch et al. 2006). The model can be used for descriptions of qualification requirements in different occupational fields, but not for measuring individuals' dispositions to master occupational tasks in different occupational situations successfully.

Approaches for external measurement of vocational competences are not recommendable for measuring competences in specific vocation areas:

1. Self assessment instruments, such as JRA or GWA, give a picture of individuals activities used in a particular workplace, not of the competences used to successfully master occupational tasks in different situations. ${ }^{13}$ Individual competences cannot be inferred from descriptions of performance in different working environments because work activities are linked to concepts of specific work organisations, which differ between firms/occupational sectors and national settings.

2. The greatest disadvantage of self-assessment as a method of obtaining data is the greater chance of measurement error, resulting from a more or less 'intentional' manipulation of answers by respondents and unintentional discrepancies between the real and reported values which results in low reliability. To measure and compare young adults` performance across countries in a valid and reliable way, objective measures of internal conditions are highly recommendable to avoid these measurement errors.

12 Leonardo da Vinci project "VQTS - Vocational Qualification Transfer System"

13 GWAs could be used for triangulations in a large-scale assessment of VET. 
3. Performance-based measurement of specific, workplace-related tasks must be based on an agreement of performance levels in different occupations in terms of occupational tasks, relevant in specific vocational areas across countries.

4. The overarching goals of VET are not sufficiently incorporate din external approaches: whereas aspects of work related qualifications are included, aspects of individual development and societal participation are not incorporated.

5. Some external approaches are very time-consuming, which is problematic in largescale assessment in terms of reaching valid, reliable and objective results at low costs (e.g., skills tests in the World Skills competition amount to 20 hours total testing time).

6. The most striking criticism regarding external measurement refers to the fact, that valid performance cannot be related to organisations and contents of VET and individuals learning and development during VET cannot be assessed.

\section{Future demands of competence measurement in VET}

To use competence measurement as an instrument for international benchmarking of VETsystems and -programmes, we need an international large-scale assessment, based on concepts for measuring internal dispositions with Item Response Theory (Rost 2006). During its council presidency, the German Government (Federal Ministry of Education and Research) adapted the discussion on quality in VET and started an initiative for an international LargeScale Assessment in VET (VET-LSA). ${ }^{14}$ The main benefit of a VET-LSA is to expand the knowledge for steering VET processes at different policy levels. VET-LSA will increase valid and reliable steering knowledge:

- to determine the relationship between individual/biographic characteristics, training forms and skill building;

- to improve transparency regarding the performance of European VET-programmes;

- to link VET-outcomes and institutional orders of VET-systems;

- to determine the correlation between the competences certified in final examinations and competences actually measured;

- to assess the comparative strength and weaknesses of different training forms in different countries to learn from each other.

14 On the policy level, the following representatives from European countries and institutions are members in the international Steering Group: Sweden, Denmark, Norway, Slovenia, Finland, Switzerland, Germany Austria, Spain, CEDEFOP, ETF, EC. 
- to classify different vocational training qualifications in international classification schemes (ISCED; EQF) in order to support the comparability of certification processes at the European level;

and others.

The development and implementation of an international large-scale assessment of VET is much more complex than in compulsory education. Whereas international student assessment programmes (e.g., PISA) are based upon well-grounded research traditions and internationally validated concepts, e.g., world curriculum for mathematics and standards in education, VET cannot draw upon comparable concepts. In a VET-LSA, the focus is on the measurement of competences in specific occupational domains not on every occupation. Contrary to international assessment programmes of students and adults (e.g., PISA, PIAAC), VET-LSA does not claim to be an overall representative survey. The aim is to include some of the most important industrial/technical, commercial/administrative, and care occupations in the sample ${ }^{15}$ (Baethge et al. 2008; Baethge et al. 2007; Baethge et al. 2006).

VET systems in different countries or even in sectors within one country are unlikely to be drawn into convergence through the Copenhagen process (2002); there is a variety of outcomes rather than conformity. To measure the same construct, the common elements in VET have to be specified first. The Feasibility Study, which is currently being developed in cooperation with experts from all countries interested in participation, ${ }^{16}$ will provide a clear picture of those national programs that are comparable and might be included in an international comparison (Baethge et al. 2008). International classification systems (ISCED, ISCO, $\mathrm{O}^{*} \mathrm{NET}$ ) are used in a first step of comparison as a frame of reference for identifying a set of core occupational task and qualification requirements in all participating countries, not as a tool for competence measurement.

One of the central requirements for an international comparison of VET with a focus on competence measurement is a common understanding of the objectives for VET. This common understanding must be mutually developed, taking into consideration different scientific and policy perspectives. The definition of objectives for VET can be based on a rather limited or on a broader approach. A broader approach encompasses individual competences in specific occupational domains and competences individuals need to participate effectively as members of a flexible, adaptable, and competitive workforce and as

15 Sweden, Denmark, Norway, Finland, Slovenia, Switzerland, Austria and Germany. France and Spain are interested in participating in VET-LSA.

16 Sweden, Denmark, Norway, Finland, Slovenia, Switzerland, Austria and Germany. France and Spain are interested in participating in VET-LSA. 
lifelong learners. In a limited approach, competences are rather focused on the requirements of the workplace. In accordance with the ongoing scientific discussion, three objectives for educational systems at the system level were determined with experts during international VET-LSA workshops (Baethge et al. 2007; Baethge and Achtenhagen 2007). These objectives have the function of reference points for the definition of competences in vocational education and training and for the development of measurement tools in a VETLSA:

- First, the development of individual vocational adjustment, from an individual user perspective and taking into consideration the central aspect of autonomy in working situations (individual perspective).

- Second, the ability to deal with today's labour markets requirements and develop one's career (human resources perspective).

- Third, the ability to participate in organisational processes of work and work-related interactions (social perspective).

To determine to what extend VET systems are able to achieve these objectives, they were operationalised in the concept of VET-LSA in cooperation with experts form different countries. The concept of VET-LSA comprises two major areas of measurement:

- Vocational and occupational domain-specific competences refer to young adults' abilities to successfully apply their knowledge and experience to authentic occupational situations in specific vocational fields (Car Mechatronics, Electricians, Business \& Administration, Social \& Health Care).

- Cross-occupational competences are related to successful performance in the labour market. They refer to the notion of key skills or “core competencies”, which comprise knowledge, skills and abilities e.g., about the structures of organisations and labour markets and acting autonomously in work environments. ${ }^{17}$

To illuminate interdependencies between domain-specific vocational and basic competencies, a third area is included in the concept for VET-LSA:

- Basic competences, such as reading, writing and mathematics which are being tested in international programmes for student or adult assessments.

17 The measurement approach for cross-occupational competences in VET-LSA differs from the approach for generic workplace skills in PIAAC. Whereas in PIAAC assessment is based on self-assessment of work activities with the JRA approach, cross-occupational competences in VET-LSA will be assessed on the basis of approaches for internal conditions. 
In addition to the measurement of young adults ' competences in VET, institutional and individual context factors impacting the development of competences during VET, are included in the concept for VET-LSA:

Institutional conditions on a macro- and meso-level refer to

- coordination and steering (actors in VET and their responsibilities, e.g. state, social partners),

- standards and norms (e.g., curricula and exams),

- $\quad$ resources (e.g., financing, professionalism of teaching staff), and

- institutional co-operation of educational service providers.

Whereas institutional conditions of VET should be measured in terms of average conditions in occupational fields (not at the institutional level) on the basis of expert interviews, organisational conditions of VET should be measured in terms of young adults' perceptions on the basis of questionnaires.

Individual conditions of educational development and background consist of:

- socio-economic status of the family (including migration),

- social and cultural capital of young adults and their families,

- educational and career development,

- information behaviour and learning activities (including non-formal learning activities), and

- educational/career aspirations.

For the quality of educational processes, the following aspects are considered important:

- focus on problem solving and task complexity within occupational contents,

- variability (multiple working tasks and tools),

- possibilities for independent task solving,

- support,

- learning climate,

- team integration, and

- quality control.

An international-large-scale assessment in VET will provide a number of indicators to compare and evaluate VET-systems and institutional arrangements in VET according to 
quality, e.g., young adults`competence levels in different competence domains, occupations and their relation to individual and institutional factors, and others. 


\section{References:}

Arends, L. (2006): Vocational competencies from a life-span perspective: Theoretical considerations and practical implications for an international large-scale assessment of vocational education and training. Norderstedt.

Ashton, D./Davies, B./Felstead, A. and Green, F. (1999): Work Skills In Britain. Oxford, SKOPE, Oxford and Warwick Universities.

Baethge M./ Arends, L. and Winther, E. (2008): First international workshop Feasibility Study VET-LSA, Discussion paper, workshop 3.-4. July, 2008 in Bonn. SOFI Göttingen.

Baethge, M./Achtenhagen, F. and Arends, L. (2008): How to Compare the Performance of VET Systems in Skill Formation. In: Mayer, K.-U. and Solga, H. (Eds.): Skill Formation - Interdisciplinary and Cross-National Perspectives. New York.

Baethge M./Achtenhagen, F./Arends, L./Winther, E./Nickolaus, R./Gschwendtner, T./Onna, M. van/Béguin, A./Sibberns, H. and Watermann, R. (2007): Concept for an International Large Scale Assessment of Vocational Education and Training (VET-LSA). Working paper for the international workshop, 29.-30. October, 2007 in Bonn. SOFI Göttingen.

Baethge, M./Achtenhagen, F./Arends, L./Babic, E./Baethge-Kinsky, V. and Weber, S. (2006): PISA-VET. A FeasibilityStudy. Stuttgart.

Copenhagen Declaration (2002): Declaration of the European Ministers of Vocational Education and Training, and the European Commission, convened in Copenhagen on 29 and 30 November 2002, on enhanced European cooperation in vocational education and training. Online: http://ec.europa.eu/education/pdf/doc125en.pdf.

Descy, P. and Tessaring, M. (2005): The value of learning : evaluation and impact of education and training: third report on vocational training research in Europe: synthesis report. Luxembourg: Office for official publications of the European Communities (Cedefop reference series; 61).

European Commission - Directorate General Education and Culture (2004): Maastricht communiqué on the future priorities of enhanced European cooperation in vocational education and training (VET): Review of the Copenhagen declaration of 30 November 2002. Brussels: European Commission. Available from Internet: http://libserver.cedefop.europa.eu/vetelib/eu/pub/ commission/dgeac/20040018en.pdf [cited: 28.9.2006].

Felstead, A./Gallie, D. and Green, F. (2002): Work Skills In Britain 1986-2001. Nottingham.

Helsinki Communiqué (2006): The Helsinki Communiqué on Enhanced European Cooperation in Vocational Education and Training. Communiqué of the European Ministers of Vocational Education and Training1, the European Social partners and the European Commission, convened in Helsinki on 5 December 20063 to review the priorities and strategies of the Copenhagen Process. Online: http://ec.europa.eu/education/policies/2010/doc/helsinkicomen.pdf.

Jeanneret, P.R./Borman, W.C./Kubisiak, U.C. and Hanson, M.A. (1999): Generalized Work Activities. In: Peterson, N.G./Mumford, M.D./Borman, W.C./Jeanneret, P.R. and Fleishman, E.A. (Eds.): An occupational information system for the 21st century: The development of O*NET. Washington, DC: American Psychological Association, 105-125.

Luomi-Messerer, K. and Markowitsch, J. (Eds.) (2006): VQTS model. A proposal for a structured description of work-related competences and their acquisition. Vienna: 3s research laboratory.

Markowitsch, J./Becker, M. and Spöttl, G. (2006): Zur Problematik eines European Credit Transfer System in Vocational Education and Training (ECVET). In: Grollmann, P./Rauner, F. and Spöttl, G.; (Eds.): Europäisierung Beruflicher Bildung - eine Gestaltungsaufgabe. Hamburg, 173-198.

Murray, T.S. and Clermont, Y. (2005): The origins and objectives of the ALL study. In Murray, T.S./Clermont, Y. and Brinkley, M.: Measuring adult literacy and life skills. New frameworks for assessment. Ottawa: Statistics Canada.

Nickolaus, R./Gschwendtner, T. and Geißel, B. (2008): Modellierung und Entwicklung beruflicher Fachkompetenz in der gewerblich-technischen Erstausbildung. In: ZBW, 104. Bd., H. 1, 48-73.

OECD (2005): Improving financial literacy: Analysis of issues and policies. OECD: Paris.

OECD (2008): Improving financial education and awareness on insurance and private pensions. OECD: Paris.

OECD and Statistics Canada (2005): Learning a Living. First results of the adult literacy and life skills survey. Paris.

Rost, J. (2006): Using Item-Response-Theorie for measuring vocational competences in an international large-scale assessment in VET - Expert report in: Baethge, M./Achtenhagen, F./Arends, L./Babic, E./Baethge-Kinsky, V. and Weber, S. PISA-VET. A Feasibility-Study. Stuttgart.

Schleicher, A. (2008): PIAAC: a new strategy for assessing adult competencies. International Review of Education.

Toolsema, B. (2003): Werken met competenties. Naar een instrument voor de identificatie van competenties. Enschede.

UNESCO (2006): ISCED 1997 International Strandard Classification of Education. Re-edition. Online: http://www.uis.unesco.org/TEMPLATE/pdf/isced/ISCED A.pdf.

Winther, E. and Achtenhagen, F. (2008): Kompetenzstrukturmodell für die kaufmännische Bildung. Adaptierbare Forschungslinien und theoretische Ausgestaltung [Translation: Competence model in the field of business and administration: state of the art and directions for further research]. Zeitschrift für Berufs- und Wirtschaftspädagogik, (104), 511-538. 